Helgoländer wiss. Meeresunters. 30, 519-526 (1977)

\title{
Studies from the "UWL Helgoland" on the macrobenthic fauna of rocks and boulders in Lübeck Bay (western Baltic Sea)
}

\author{
B. GULLIKSEN
}

Biological Station; Trondheim, Norway

\begin{abstract}
ABST'RACT: During a fortnight's saturation mission with the Underwater Laboratory (UWL) "Helgoland" in May and June 1975, samples of the macrobenthic fauna of rocks and boulders at $15 \mathrm{~m}$ depth in the Luibeck Bay were collected from the same area as in October 1974, using a diver-operated suction sampler. Salinity varied from $11.1 \%$ to $15.0 \% 0 \mathrm{~S}$ and water temperature from $7.5^{\circ} \mathrm{C}$ to $11.5^{\circ} \mathrm{C}$. Visibility was usually about 3 to $4 \mathrm{~m}$. On average, 10.449 individuals $/ \mathrm{m}^{2}$ were recorded in 1975 compared to 30.474 individuals $/ \mathrm{m}^{2}$ in 1974 . Two species, the ascidian Dendrodoa grossularia and the polychaete Polydora ciliata account for $90.8 \%$ of the total number of individuals sampled. Five species (Dendrodoa grossularia, Nereimyra punctata, Neoamphitrite figulus, Asterias rubens, Facelina drummondi) were significantly less abundant than in 1974, while two species and one group of species (Anaitides maculata, Corophium bonelli, Nemertini indet.) were more abundant in 1975. As in 1974, the angle of inclination of the substrate showed no relationship with species composition. In 1974, four motile benthic invertebrates, Nereimyra punctata, Idothea baltica, Diastylis ratbkei, and Facelina drummondi were observed swarming. In 1975, only I. baltica was observed swarming and the individuals seemed to be less active than in 1974 , perhaps related to the lower water temperatures recorded in May and June 1975 compared to those in October 1974.
\end{abstract}

\section{INTRODUCTION}

The benthic fauna of rocks and boulders in the Lübeck Bay (western Baltic Sea) was investigated from May 28, to June 13, 1975, during a study visit to the Underwater Laboratory (UWL) "Helgoland"; it represented a continuation of the study made between October 5 and 19, 1974 (Gulliksen, 1975). The second study was intended to provide more information about faunal composition and any swarming of the motile benthic invertebrates in the area.

\section{STUDY AREA}

During the spring of 1975 , the UWL was located in the Lübeck Bay, NW of Travemünde $\left(54^{\circ} 01^{\prime} 04^{\prime \prime} \mathrm{N}, 10^{\circ} 50^{\prime} 04^{\prime \prime} \mathrm{E}\right)$ at $15 \mathrm{~m}$ depth. The area chosen was situated only about $100 \mathrm{~m}$ east of that investigated in October 1974 and the same rocks and boulders could be sampled as on the previous occasion. 
Salinity near the bottom varied this time from $11.1 \%$ to $15.0 \% \mathrm{~S}$ and the water temperature from $7.5^{\circ} \mathrm{C}$ to $11.5^{\circ} \mathrm{C}$. Rapid changes in the hydrographical conditions occurred, e.g. on June 29 , the temperature fell from $11.5^{\circ} \mathrm{C}$ to $7.5^{\circ} \mathrm{C}$ in the course of $15 \mathrm{~h}$, and salinity increased from $11.5 \%$ to $13.4 \% \mathrm{~S}$. Water visibility varied from $0.5 \mathrm{~m}$ to $7 \mathrm{~m}$ during the mission. Algal growths were mostly 10 to $15 \mathrm{~cm}$ long fronds of red algae, mainly Delesseria sanguinea, Phyllophora sp. and Pbycodris sp., which were concentrated on the upper surfaces of the rocks and boulders.

\section{MATERIAL AND METHODS}

For ease of comparability, samples were collected the same way as in 1974 (Gulliksen, 1975), using the diver-operated suction sampler, previously described by Gulliksen \& Derås (1975). This sampler is designed to collect the macrofauna, i.e. all animals which are retained by a $0.5 \mathrm{~mm}$ sieve (McIntyre, 1964; Holme \& McIntyre, 1971).

Twenty-eight samples were collected. Sample size was $1.78 \mathrm{dm}^{2}$. The angle of inclination of the bottom was noted for each sample. Further information concerning the sampling method and sorting of the samples are given in Gulliksen (1975).

The swarming of motile benthic invertebrates was studied by direct observation and with the use of a simple trap. The trap was composed of five glass jars, with a mouth diameter of $7.8 \mathrm{~cm}$, mounted in a line laterally about $15 \mathrm{~cm}$ apart, and all suspended about $0.5 \mathrm{~m}$ above the bottom. The bases of the jars were wider than their mouths. Motile benthic invertebrates were intended to swim into the jars accidentally while swarming and so become trapped. The jars were closed in situ, brought back to the UWL, sieved through a $0.5 \mathrm{~mm}$ mesh sieve and the contents examined under a high-power lens.

\section{RESULTS}

\section{Faunal composition}

In the 28 suction samples, covering a total bottom area of $49.84 \mathrm{dm}^{2}$, at least 35 different macrofaunal species were found (Table 1). The most abundant species were the ascidian Dendrodoa grossularia (van Beneden) and the polychaete Polydora ciliata (Johnston), which together accounted for $90.8 \%$ of the total number of individuals. These two species were also the most abundant in 1974, when they accounted for $95.6 \%$ of the total number of individuals collected (Gulliksen, 1975).

The mean abundance was lower in 1975 in comparison to 1974 . A mean number of 10.449 individuals $/ \mathrm{m}^{2}$ was recorded in 1975 , compared with 30.474 individuals $/ \mathrm{m}^{2}$ in 1974 .

Many halacarids and nematodes were caught in the 1975 samples. The individual specimens were mostly found intermingled with algae, bryozoans and hydrozoans. Halacarids and nematodes are commonly treated as meiobenthos (Hulings \& Gray, 1971) and are therefore not included in Table 1. However, all the individuals be- 
Studies on macrobenthic in Lübeck Bay

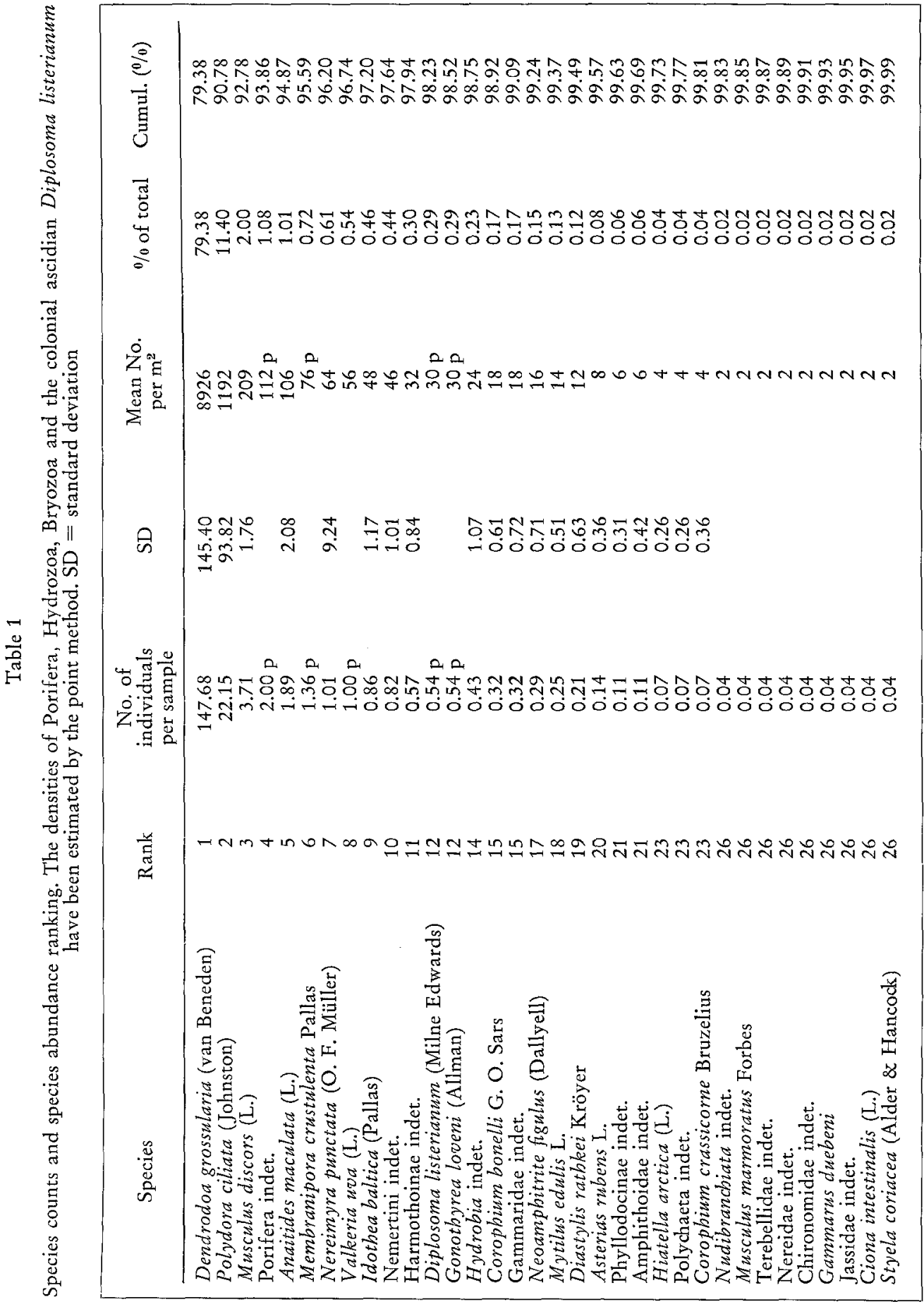


longing to these two groups which were retained by the sieve were counted. The recorded mean densities of halacarids and nematodes were 3796 and 2885 individuals per $\mathrm{m}^{2}$, respectively. These figures would undoubtly have been much higher had a sieve with a finer mesh been used.

The results for all those macrobenthic species which occurred in more than $10 \%$ of the samples in either 1974 and 1975 were tested statistically (Student's t-test, see Table 2) to see if real changes had taken place in the mean densities and frequencies

\section{Table 2}

The frequencies of all species which occurred in at least $10 \%$ of the samples in either 1974 og 1975. $t_{1}$ are values obtained with Student's $t$-test by comparison of frequencies, t2 are values obtained by comparison of densities in 1974 and 1975 . Significant differences $(P>1 \%$ ) between the 1974 and 1975 values are marked with an asterix

\begin{tabular}{|lcccc|}
\hline \multicolumn{1}{|c}{ Species } & $\begin{array}{c}\text { Frequency } \\
\text { in } 1975\end{array}$ & $\begin{array}{c}\text { Frequency } \\
\text { in } 1974\end{array}$ & t 1 & t2 \\
\hline Dendrodoa grossularia & 1.0 & 1.0 & 0 & $2.96^{*}$ \\
Polydora ciliata & 0.86 & 0.73 & 1.24 & 1.84 \\
Musculus discors & 0.75 & 0.61 & 1.20 & 1.90 \\
Porifera indet. & 0.93 & 0.85 & 0.99 & \\
Anaitides maculata & 0.64 & 0.06 & $4.85^{*}$ & $4.88^{*}$ \\
Membranipora crustulenta & 0.86 & 0.61 & 2.18 & \\
Nereimyra punctata & 0.64 & 0.88 & 2.17 & $4.62^{*}$ \\
Valkeria uva & 0.57 & 0.72 & 1.30 & 1.47 \\
Idothea baltica & 0.46 & 0.55 & 0.63 & $3.45^{*}$ \\
Nemertini indet. & 0.54 & 0.12 & $3.55^{*}$ & 0.86 \\
Harmothoinae indet. & 0.39 & 0.30 & 0.75 & \\
Diplosoma listerianum & 0.39 & 0.03 & $3.52^{* *}$ & \\
Gonthyrea loveni & 0.46 & 0 & $4.38^{* *}$ & \\
Hydrobia indet. & 0.21 & 0.15 & 0.62 & $3.02^{*}$ \\
Corophium bonelli & 0.25 & 0 & $3.06 *$ & 0.76 \\
Gammaridae indet. & 0.21 & 0.06 & 1.80 & 2.31 \\
Neoamphitrite fgulus & 0.18 & 0.52 & $2.73^{*}$ & 1.16 \\
Mytilus edulis & 0.21 & 0.27 & 0.52 & 1.79 \\
Diastylis ratbkei & 0.14 & 0.24 & 1.00 & $3.71^{*}$ \\
Asterias rubens & 0.14 & 0.68 & $4.33^{* *}$ & 1.28 \\
Phyllodocinae indet. & 0.11 & 0.03 & 1.13 & $3.46^{*}$ \\
Facelina drummondi & 0 & 0.36 & $3.56^{*}$ & 0.98 \\
Hiatella arctica & 0.07 & 0.15 & 1.00 & \\
\hline
\end{tabular}

of occurrence in the time elapsing between the two investigations. The density values for colonial organism were not tested. The density values for 1974 have previously been reported by Gulliksen (1975) and are not included again here.

Five organisms (Dendrodoa grossularia, Nereimyra punctata [O. F. Müller], Neoamphitrite figulus [Dallyell], Asterias rubens L., Facelina drummondi [Thompson])

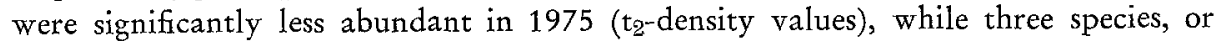
really group of species (Anaitides maculata [L.], Corophium bonelli G. O. Sars, Nemertini indet.) were significantly more abundant in 1975 . The frequency values $\left(t_{1}\right)$ show that three organisms occurred less frequently in the 1975-samples than those in 1974 (N. figulus, $A$. rubens, $F$, drummondi), while five organisms were more frequent (A. maculata, Diplosoma listerianum [Milne Edwards], Gonotbyrea loveni [Allman], C. bonelli, Nemertini indet.). 
Table 3

Spearman's rank correlation coefficients and density rankings at different angles of inclination of the substrate

\begin{tabular}{|c|c|c|c|c|}
\hline \multirow[b]{2}{*}{ Species } & \multicolumn{4}{|c|}{ Angle of inclination of the substrate } \\
\hline & $\begin{array}{l}\text { O-29 } \\
\text { Rank }\end{array}$ & $\begin{array}{c}30^{\circ}-59^{\circ} \\
\text { Rank }\end{array}$ & $\begin{array}{c}60^{\circ}-89^{\circ} \\
\text { Rank }\end{array}$ & $\begin{array}{c}90^{\circ}-180^{\circ} \\
\text { Rank }\end{array}$ \\
\hline Dendrodoa grossularia & 1 & 1 & 1 & 1 \\
\hline Polydora ciliata & 2 & 2 & 2 & 2 \\
\hline Musculus discors & 3 & 3 & 4 & 6 \\
\hline Porifera indet. & 5 & 4 & 3 & 15 \\
\hline Anaitides maculata & 4 & 5 & 5 & 3 \\
\hline Membranipora crustulenta & 6 & 7 & 7 & 6 \\
\hline Nereimyra punctata & 7 & 10.5 & 7 & 15 \\
\hline Valkeria uva & 10 & 5 & 7 & 15 \\
\hline Idothea baltica & 9 & 8 & 12.5 & 15 \\
\hline Nemertini indet. & 8 & 14 & 12.5 & 15 \\
\hline Harmothoinae indet. & 14 & 10.5 & 10.5 & 15 \\
\hline Diplosoma listerianum & 11 & 13 & 14 & 15 \\
\hline Gonothyrea loveni & 19.5 & 10.5 & 9 & 6 \\
\hline Hydrobia indet. & 14 & 17 & 10.5 & 6 \\
\hline Coropbium bonelli & 19.5 & 10.5 & 20 & 15 \\
\hline Gammaridae indet. & 14 & 16 & 17 & 15 \\
\hline Neodmphitrite figulus & 12 & 19.5 & 17 & 6 \\
\hline Mytilus edulis & 17.5 & 15 & 20 & 15 \\
\hline Diastylis ratbkei & 16 & 19.5 & 17 & 15 \\
\hline Asterias rubens & 17.5 & 19.5 & 20 & 15 \\
\hline \multirow[t]{3}{*}{ Phyllodocinae indet. } & 5 & 19.5 & 14 & 15 \\
\hline & \multicolumn{4}{|c|}{$-0.782^{* * *}-0.841^{* * *}-0.67 *$} \\
\hline & & \multicolumn{3}{|c|}{$\overline{0.53 * 1}$} \\
\hline Tabulated $5 \%=0.46,1$ & & & & \\
\hline
\end{tabular}

Spearman's rank correlation method (Spearman, 1904) was used to see if the species composition was related to the angle of inclination of the substrate. The samples were arranged in four groups and the organisms within each group ranked according to their mean density values (Table 3). All species which occurred in more than $10 \%$ of the samples were considered. The rank correlations between all possible combinations of the four groups show that in species composition and mutual ranking all four group are quite similar (Table 3). This finding suggests that the angle of inclination of the substrate is relatively unrelated to the species composition of macrobenthic fauna of rocks and boulders in this area.

\section{S w a r m ing}

The motile benthic invertebrates were observed to be much less active in May and June 1975, in comparison to October 1974. The only species which were observed swimming freely in the water in 1975 were individuals of the crustacean Idothea baltica (Pallas). However, they did not seem to swim as vigorously as they did in the 
autumn of 1974. The mean numbers of individuals of this species found in the suction samples in 1975 were also lower than in 1974, viz. 48 individuals $/ \mathrm{m}^{2}$ in 1975 an 80 individuals $/ \mathrm{m}^{2}$ in 1974.

The polychaete Nereimyra punctata, the cumacean Diastylis ratbkei Kröyer and the nudibranch Facelina drummondi, all of which were observed swarming in the UWL-area in autumn 1974, were not observed swarming in spring 1975. F. drummondi, in fact, was not even recorded in the suction samples in 1975, and the mean densities of both $N$. punctata and $D$. ratbkei were lower than those recorded in 1974 .

Few swarming organisms were caught in the collecting jars. On the first night of sampling, from June 28 to 29, two individuals of $I$. baltica were caught. In the subsequent ten days and nights, no organisms at all were trapped. On June 29, a sudden fall in water temperature took place, from $11.5^{\circ} \mathrm{C}$ to $7.5^{\circ} \mathrm{C}$, and temperatures above $10^{\circ} \mathrm{C}$ were not recorded during the remaining period of the mission.

After nightfall, large accumulations of zooplankton were occasionally encountered in the entrance to the "wet-room" of the UWL. They were probably attracted by the light. Psendocalanus elongatus Boeck ( $\hat{\sigma} \hat{0}$ and $\phi$ 우) was the dominant species, but some specimens of Temora longicornis Müller ( $\hat{\delta} \hat{\sigma}$ and $\phi ㅇ$ ) and several cladocerans were also observed.

\section{DISCUSSION}

Taken as a whole, no profound changes in the species composition seemed to have taken place between the time of investigations in 1974 and those in 1975. The most abundant organisms in 1974 were generally also the most abundant ones in 1975 . However, mean densities were lower during the spring of 1975. Most of the individuals collected in the spring probably belonged to populations which were previously present in 1974. Mortality during the winter had presumably reduced population densities.

Many of the macrobenthic species in this area of the western Baltic Sea often start spawning in April and May, and spawning continues throughout the summer. It would appear the juvenile stages had not yet exerted any considerably influence on faunal composition.

Some organisms occurred more frequently in the 1975 spring samples than in the 1974 autumn samples, viz. Anaitides maculata, Diplosoma listerianum, Gonothyrea loveni, Corophium bonelli and Nemertini indet. For some of these species these higher spring frequencies can partly by explained from previous knowledge of their distribution and biology.

The colonial ascidian, D. listerianum, reproduces sexually from May to October, but has an asexual reproduction period during the autumn and from May to July in Danish waters (Lützen, 1967). The presence of D. listerianum in the 1975 samples is probably due to colonies which had already settled in 1974, but which were too small to be recorded in the autumn samples. Subsequent asexual reproduction, which may have started in May, led to the development of colonies which were conspicuous enough to be detected in the spring samples. 
The irregular nature of the occurrence of $G$. loveni throughout the year has been reported previously. In the Oslofjord, G. loveni was recorded by Christiansen (1972) only between February and August. Broch (1910) also noted its absence there in the autumn and winter. Long-term photographic observations in the Borgenfjord, Central Norway (Gulliksen, in prep.) have shown that hydrozoan colonies are most abundant during the spring. Heavy sedimentation during the summer exterminates most of these colonies. Similar reasons may explain the almost complete absence of hydrozoans in the UWL-area in the autumn, since this lies near the mouth of the river Trave.

The Anaitides specimens were specifically identified as being Anaitides maculata, although it is difficult to distinguish this species from $A$. mucosa (Anger, 1975). Hartmann-Schröder (1971) has reported $A$. maculata spawning from February to May. Anger (1975) found, in an area near Kiel, that ripe individuals of $A$. mucosa were dominant from November to May, and that they spawned during the winter and spring. The larvae migrated towards the bottom in the summer (June), at approximately the same time as most of the adults died. There is therefore probably a greater chance of finding large individuals of the species which would be retained by the sieve in springtime rather than in the autumn. The likelihood, therefore, is that either $A$. maculata and $A$. mucosa possess similar reproduction patterns, or that some of the specimens identified as $A$. maculata may in fact be $A$. mucosa.

The occurrence of Corophium bonelli in the spring samples differs somewhat from the usual observations of species belonging to this genus in the western Baltic Sea, e.g. Schütz (1964) found that C. insidiosum was most abundant during the late summer in the "Schwentine-Mündung" area.

The higher frequency of Nemertini in the spring samples will not be discussed any further here, since this group was not identified down to the species level.

The use of the mean frequency and mean density values as measures of the degree of change in faunal composition yielded almost identical results, but using both parameters gave more information than use of only a single parameter. Dendrodoa grossularia, for instance, was found to be less abundant in 1975, but was no less frequent, since it occurred in all the samples in both years. Changes in mean density values for the colonial organisms were not tested, because the "point-method" is a relatively crude one, but the frequency values yielded valuable information, e.g. Diplosoma listerianum and Gonotbyrea loveni proved to be significantly more frequent in the 1975 samples.

Compared to the autumn of 1974, considerably less swarming of the motile benthic invertebrates was observed in 1975 . Water temperatures varied from $11^{\circ} \mathrm{C}$ to $14^{\circ} \mathrm{C}$ in 1974 , and Diastylis rathkei was not observed swarming at the lower temperature (Gulliksen, 1975). In 1975, Idothea baltica was not caught in the collecting jars after days on which the water temperature fell from $11.5^{\circ} \mathrm{C}$ to $7.5^{\circ} \mathrm{C}$. Too little material was obtained with the collecting jars alone to allow any conclusions to be drawn (only two individuals were caught). However, the fact that both these individuals were caught when the temperature was at its highest supports some of the findings of 1974, which suggested that water temperature is an important factor for the swarming of the motile benthic invertebrates. 
Acknowledgements. I am grateful to the "Gesellschaft für Kernenergieverwertung in Schiffbau und Schiffahrt" and to their UWL-crew for excellent service and support. Professor Dr. philos. G. Sundnes and Dr. M. Diehl gave advice and encouragement. Thanks are also due to Mr. A. Aarset, Mr. K. M. Derås and Mr. J. Mork for assistance during the preparation, sampling and sorting of the material, and to $\mathrm{Mr}$. T. Holthe for criticism of the manuscript. Mr. P. A. Tallantire has corrected the English text. A travel grant was kindly provided by The Royal Norwegian Society for Sciences and Letters, The Museum. This paper represents contribution No. 191 from Biological Station, Trondheim.

\section{LITERATURE CITED}

Anger, K., 1975. Die Auswirkung kommunaler Abwässer auf ein ufernahes Partialökosystem der westlichen Ostsee. Diss., Univ. Kiel, 327 pp.

Brod, H., 1910. Fauna Droebachiensis. I. Hydroiden. Nyt. Mag Naturvid. 49, 1-47.

Christiansen, B. O., 1972. The hydroid fauna of the Oslo fjord in Norway. Norw. J. Zool. 20, 279-310.

Gulliksen, B., 1975. The macrobenthic fauna of rocks and boulders in the Lübeck Bay (Western Baltic Sea) investigated from the Underwater Laboratory "Helgoland". Helgoländer wiss. Meeresunters. 27, 439-449.

- \& Derås, K. M., 1975. A diver-operated suction sampler for fauna on rocky bottom. Oikos 26, 246-249.

Hartmann-Schröder, G., 1971. Annelida, Borstenwürmer, Polychaeta. Tierwelt Dt1. 58, 1-594.

Holme, N. A. \& McIntyre, A. D., 1971. Methods for the study of marine benthos. Blackwell, Oxford, 333 pp.

Hulings, N. C. \& Gray, J. S., 1971. A manual for the study of Meiofauna. Smithson. Contr. Zool. 78, 1-84.

Lützen, J. G., 1967. Sækdyr. Danm. Fauna 75, 1-267.

McIntyre, A. D., 1964. Meiobenthos of sublittoral muds. J. mar. biol. Ass. U.K. 44, 665-675.

Schütz, L., 1964. Die tierische Besiedlung der Hartböden in der Schwentinemündung. Kieler Meeresforsch. 10, 198-217.

Spearman, C., 1904. The proof and measurement of association between two things. Am. J. Psychol. 15, 72-101.

Author's address: B. Gulliksen

Universitetet Tromsø

Marinbiologisk Stasjon, $\mathrm{Pb} 2550$

N-9001 Tromsø

Norway 